\title{
Meat and Bone Meal as a Renewable Energy Source in Cement Kilns: Investigation of Optimum Feeding Rate
}

\author{
W.K.H. Ariyaratne ${ }^{1}$, M.C. Melaaen ${ }^{1}$, K. Eine ${ }^{2}$ and L.A. Tokheim ${ }^{1}$ \\ ${ }^{1}$ Department of Process, Energy \& Environmental Technology \\ Telemark University College \\ Kjølnes Ring 56, P.O. Box 203, N-3901, Porsgrunn (Norway) \\ Phone number:+47 355751 35, Fax number:+47 355754 01, e-mail: hiromi.ariyaratne@hit.no, Lars.A.Tokheim@hit.no \\ ${ }^{2}$ Norcem AS Brevik, P.O. Box 98, N-3991, Brevik (Norway) \\ Phone number:+47 355720 00, Fax number:+47 355717 47, e-mail: kristin.eine@norcem.no
}

\begin{abstract}
Meat and Bone Meal (MBM) is a $\mathrm{CO}_{2}$ neutral fuel, and hence is a good candidate for substituing fossil fuels like pulverized coal in rotary kiln burners used in cement kiln systems. MBM is used in several cement plants, but the optimum substitution rate has apparently not yet been fully investigated. The present study aims to find the maximum possible replacement of coal by MBM, without negatively affecting the product quality, emissions and overall operation of the process. A full-scale experiment was carried out in the rotary kiln burner of a cement plant by varying the MBM substitution rate from 0 to $7 \mathrm{t} / \mathrm{hr}$. Clinker quality, emissions and other relevant operational data from the experiment were analysed. Additionally, coal and MBM were compared by laboratory experiments. The results revealed that MBM could safely replace more than $40 \%$ of the coal energy without giving negative effects. The limiting factor is the free lime content of the clinker. Possible explanations to the free lime increase are given. If $40 \%$ of the coal in the rotary kiln burner was replaced by MBM on a long-term basis, the total annual $\mathrm{CO}_{2}$ emissions of the plant could be reduced by $10 \%$.
\end{abstract}

\section{Key words}

Meat and bone meal, Alternative fuel, Carbon dioxide, Rotary kiln, Free lime

\section{Introduction}

The cement production process is highly energy-intensive and generates a world average $\mathrm{CO}_{2}$ emission of $0.81 \mathrm{~kg}$ per kg cement produced [1]. The calcination of carbonates in the raw materials accounts for roughly $60 \%$ of the $\mathrm{CO}_{2}$ emitted, while the remaining carbon dioxide results from combustion of fuels in the kiln system [2]. Although coal, petroleum coke and other fossil fuels traditionally have been burnt in cement kilns, many cement plants have turned to energy-rich alternative fuels due to economical and environmental benefits. The replacement of coal by carbon dioxide neutral fuels will reduce net carbon dioxide emissions to the atmosphere, while letting the manufacturer gain economic advantages by reducing fuel costs and possibly earning $\mathrm{CO}_{2}$ allowances under an Emissions Trading scheme [3].

In modern precalciner cement kilns typically $60 \%$ of the fuel energy is supplied in the precalciner, whereas the remaining $40 \%$ is supplied via the rotary kiln burner. The operating temperature in the calciner is around $900{ }^{\circ} \mathrm{C}$ as the decarbonation of calcium carbonate occurs at this temperature. In contrast, the flame temperature in the rotary kiln burner typically should be around $2000{ }^{\circ} \mathrm{C}$ to ensure sufficient formation of melt in the solid materials being processed. Traditionally, solid alternative fuels are fed to the calciner rather than to the kiln burner, partly because of the lower temperature, partly because gravitation-facilitated feeding can be implemented in the calciner. This also allows for feeding of lumpy fuels. However, in the kiln main burner, solid fuels have to be ground into a fine meal and then fed pneumatically into the rotary kiln. There are examples of plants replacing as much as $90 \%$ of the coal energy in the calciner by solid waste fuels [4], [5], provided the feeding and processing of the alternative fuels are done properly [2]. When the replacement potential in the calciner is fully utilized, one may turn to the kiln burner to increase the overall fossil energy replacement ratio even more.

The range of alternative fuels is very wide. Meat and bone meal - MBM (also called animal meal) is used in several cement kilns, in particular in Western Europe. The fuel is prepared by post-treating (grinding and sterilizing) the waste materials associated with slaughtering operations. Since it contains only biogenic materials it can be categorised as $100 \%$ biomass fuel which gives no net carbon dioxide emissions during the combustion process. 
Compared to partly $\mathrm{CO}_{2}$ neutral fuels, another advantage of using a $100 \%$ biofuel, is that one does not have to determine the fossil fraction of a mixed fuel, which can be a challenge [6].

Although MBM is already widely used as an alternative fuel in cement kiln main burners, it is hard to find scientific investigations of optimum usage of MBM in cement kilns. However, one study has been carried out to find out the effect of MBM ash addition on the clinkering process and hydraulic reactivity of clinker [7]. In another study [8] the air demand and energy input in the rotary kiln burner were investigated through an ASPEN PLUS model by partly replacing primary fuel by MBM.

Furthermore, numerous studies on MBM characteristics and co-combustion in fluidised beds have been published. Several proximate and ultimate analyses of MBM have been found, some including additional elemental analyses as well [8]-[13]. MBM residues are mainly due to bones, which have high amounts of calcium (30.7\%) and phosphate (56.3\%) [14]. Not only pure MBM [9], [14], [15] but also different coal-MBM blends [10] were analysed in Thermo Gravimetric Analysis (TGA) in numerous studies to investigate thermal behaviour under reducing and oxidizing conditions. The chemical kinetics for devolatilization of MBM was also studied [16], [17]. Furthermore, different aspects of fluidised bed and power plant co-combustion of MBM with other fuels were investigated by several authors [11]-[13], [18]-[21].

The main objective of the present study was to find the maximum possible replacement of coal by MBM without negatively affecting the product quality, emissions and overall operation of the process. A full-scale experiment was carried out in a cement plant which annually produces 1.3 million tons of cement. The bottleneck of using higher amounts of MBM in the rotary kiln burner was investigated, and possible reasons were analysed by evaluating process and quality data as well as by comparing physiochemical properties of coal and MBM. Finally, the optimum feed level was concluded for that specific kiln system considering long term operation, and the $\mathrm{CO}_{2}$ emission reduction was documented.

\section{Method}

Full-scale experiments were carried out to investigate the impact of MBM feeding rate on the cement kiln process and the product quality. Additionally, coal and MBM were characterised through laboratory experiments, including determination of proximate analysis, major oxides, heating value, bulk density and particle size distribution.

\section{A. Fuel characterization}

Laboratory analyses were carried out for characterization of the coal and the MBM used in the full-scale experiments. The proximate analysis was carried out using a Perkin-Elmer TGA instrument (model: TGA 7) by applying different temperature steps up to $750{ }^{\circ} \mathrm{C}$. The heating value was determined by a Leco AC-350 automatic calorimeter. The bulk density was measured by weighing a known freely distributed volume. The particle size was analysed by a Helos KF-Magic laser diffraction instrument and by mechanical sieving.

Additional chemical analyses of the fuels were available from the plant laboratory.

\section{B. Full-scale experiments}

A full-scale test was carried out in a modern 4-stage, 2string precalciner cement kiln system at a Norwegian cement plant with several years of experience in burning $\mathrm{MBM}$ at relatively low rates as a coal replacement in the rotary kiln burner. The kiln is $68 \mathrm{~m}$ long and $4.4 \mathrm{~m}$ in diameter. It is equipped with a modified KHD Pyrojet burner at the kiln outlet (where the hot clinker is discharged from the kiln), with three different tubular fuel inlets for solid and liquid alternative fuels and one annular inlet for coal, see Figure 1. The solid alternative fuel is fed via a Pfister feeder system designed to control mass feeding of solid secondary fuels up to $7 \mathrm{t} / \mathrm{hr}$. When material passes through the rotor weighfeeder, the momentum is measured by load cells, and the rotor angular speed is calculated according to the mass flow rate set point [22].

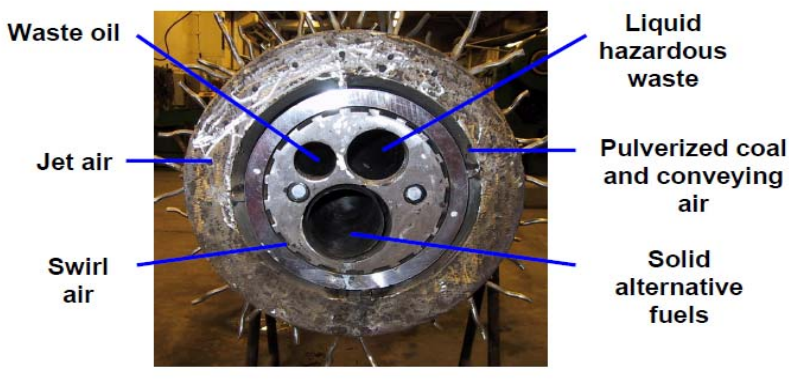

Fig. 1. Kiln burner

The test was carried out for 12 hrs by varying the MBM feeding rate in particular time intervals. MBM was fed via the Pfister system described above. Ordinary portland cement (OPC) clinker was produced. The raw meal feeding rate was kept at $220 \mathrm{t} / \mathrm{hr}$; however, the feeding rate had to be reduced by $10 \mathrm{t} / \mathrm{hr}$ at the final stage of the experiment to keep the clinker quality within the desired range.

The conditions in the precalciner and in the kiln were kept stable throughout the experiment. The raw material composition and feeding rate, the conventional and alternative fuel supply rates and the bypass stream were maintained at constant levels in order to keep the degree of calcination of hot meal and the thermal energy consumption constant during the test. The ratio of thermal energy consumption between main burner and calciner was kept at 42:58. The MBM feeding rate was gradually increased by reducing coal supply in order to keep the thermal energy consumption of the kiln at almost constant level.

1) Experimental plan. Table I shows the experimental schedule and thermal energy 
replacement by MBM in the main burner. The lower heating values of $\mathrm{MBM}$ and coal were $4423 \mathrm{kcal} / \mathrm{kg}$ and $6689 \mathrm{kcal} / \mathrm{kg}$ respectively (Table II).

Table I. - Experimental schedule

\begin{tabular}{|l|c|c|c|}
\hline Time interval & $\begin{array}{c}\text { MBM } \\
\text { feeding } \\
\text { rate (t/hr) }\end{array}$ & $\begin{array}{c}\text { Coal } \\
\text { feeding } \\
\text { rate (t/hr) }\end{array}$ & $\begin{array}{c}\text { Energy } \\
\text { substitution } \\
\text { at main } \\
\text { burner (\%) }\end{array}$ \\
\hline $9.00-11.00$ & 0 & 7.8 & 0.0 \\
\hline $11.00-13.00$ & 2 & 6.5 & 16.9 \\
\hline $13.00-15.00$ & 4 & $5.0-5.5$ & 33.5 \\
\hline $15.00-17.00$ & 5 & 4.5 & 42.4 \\
\hline $17.00-19.00$ & 6 & 3.9 & 50.4 \\
\hline $19.00-21.00$ & 7 & $3.0-3.4$ & 59.1 \\
\hline
\end{tabular}

2) Data collection. The average process data (emissions, operation of Pfister feeder) were collected through a plant database system in one minute intervals during the whole experiment.

Important clinker properties were analysed in 1 or $2 \mathrm{hr}$ time intervals. The clinker samples were collected from the apron conveyor after the cooler. Clinker samples were collected just before the changes in the MBM feeding rates were made. The oxides were analysed with a Philips PW 2404 x-ray spectrometer using the xray fluorescence (XRF) method, and the $\mathrm{SO}_{3}$ content was analysed by means of an ELTRA CS 800 carbon-sulphur analyzer. The ethylglycol method was used for analysis of free lime (uncombined $\mathrm{CaO}$ ) in the clinker.

\section{Results \& Discussion}

This section presents the results from laboratory and fullscale experiments. First the fuel characteristics determined in the lab are given. Then impacts on the clinker quality and on the process are discussed. Finally, $\mathrm{CO}_{2}$ savings attributed to replacement of coal by MBM is presented.

\section{A. Fuel characterization}

The properties of coal and MBM are given in Table II.

Table II. - Properties of coal and MBM

\begin{tabular}{|l|c|c|}
\hline \multicolumn{1}{|c|}{ Property } & Coal & MBM \\
\hline Moisture (wt.\%) & 1.0 & 4.0 \\
\hline Volatiles (wt.\%) & 31.6 & 60.8 \\
\hline Fixed carbon (wt.\%) & 56.3 & 8.0 \\
\hline Ash (wt.\%) & 11.1 & 27.2 \\
\hline $\mathrm{P}_{2} \mathrm{O}_{5}$ (wt.\%) & 0.07 & 13.0 \\
\hline CaO (wt.\%) & 0.20 & 13.3 \\
\hline Lower heating value (kcal/kg) & 6689 & 4423 \\
\hline Freely settled density $\left(\mathrm{kg} / \mathrm{m}^{3}\right.$ ) & 640 & 720 \\
\hline
\end{tabular}

The cumulative distributions of coal and MBM particle sizes are shown below. The particle size will affect the burnout time of the particles in the kiln; this is further discussed in Subsection 3B.

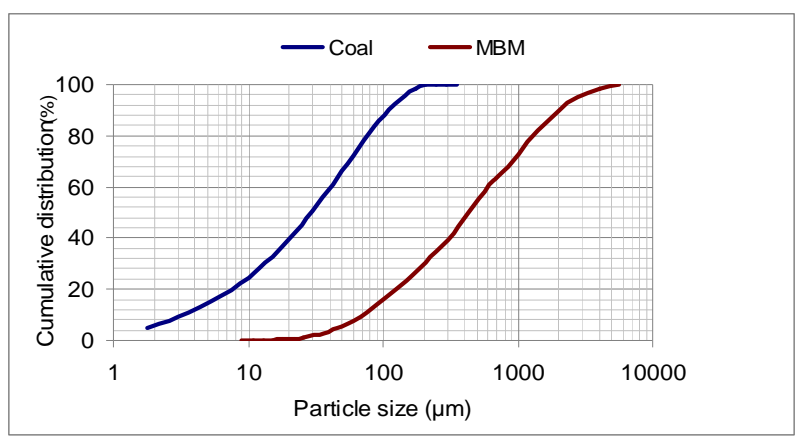

Fig. 2. Cumulative particle size distribution

\section{B. Clinker quality}

Figure 3 represents the main oxides of clinker. These were all at desirable levels to maintain an acceptable clinker quality throughout the experiment.

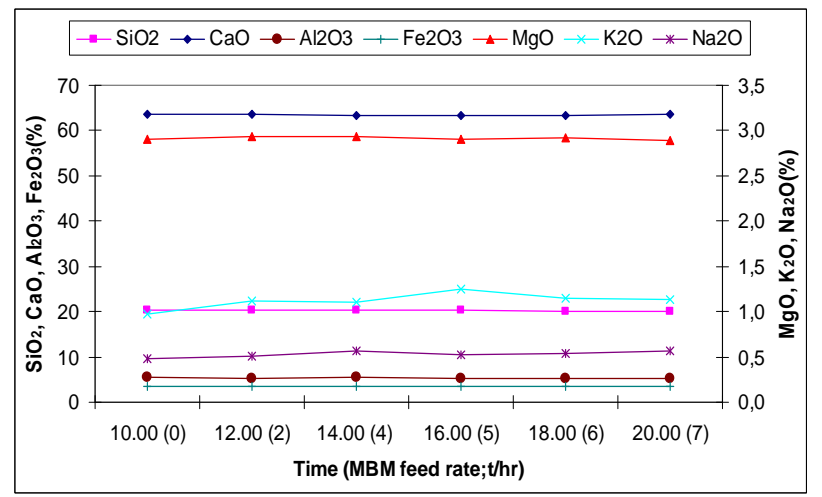

Fig. 3. Main oxides of clinker

Among the results, emphasis was put on the content of free lime, phosphorus and sulphur content in the clinker, as these parameters might be impacted by feeding high rates of MBM. A high level of free lime $(\mathrm{CaO})$ would indicate that part of the $\mathrm{CaO}$ had not combined properly with the main acidic oxides $\mathrm{SiO}_{2}, \mathrm{Al}_{2} \mathrm{O}_{3}$ and $\mathrm{Fe}_{2} \mathrm{O}_{3}$ in the raw materials, and a poor clinker quality would be the result. Accordingly, the free lime level is the main quality parameter monitored by the kiln operators. The level should not be higher than $2.5 \%$ for OPC production. Though there is no absolute recommended limitation for phosphorus (measured as $\mathrm{P}_{2} \mathrm{O}_{5}$ ) in the clinker, the typical maximum limit is taken as $2 \%$, as higher values may give concrete expansions when the product is used. Some cement plants have even lower internal maximum limits to be on the safe side. Typically MBM contains $13 \% \mathrm{CaO}$ and $13 \% \mathrm{P}_{2} \mathrm{O}_{5}$ respectively (Table II). MBM does not have high concentrations of sulphur (measured as $\mathrm{SO}_{3}$ ), but changes in the $\mathrm{SO}_{3}$ content in clinker might be due to process-disturbing changes in the internal sulphur cycles in the kiln system [2], potentially induced by changes in the combustion conditions in the main burner as a result of the MBM feeding. The results are shown in Figure 4.

MBM has a high phosphorus content compared to other fuel types, and consequently the $\mathrm{P}_{2} \mathrm{O}_{5}$ content in the clinker increases with increasing feeding rates of MBM. However, the $\mathrm{P}_{2} \mathrm{O}_{5}$ in the clinker is at an acceptable level even at the maximum feeding rate of $7 \mathrm{t} / \mathrm{hr}$. 


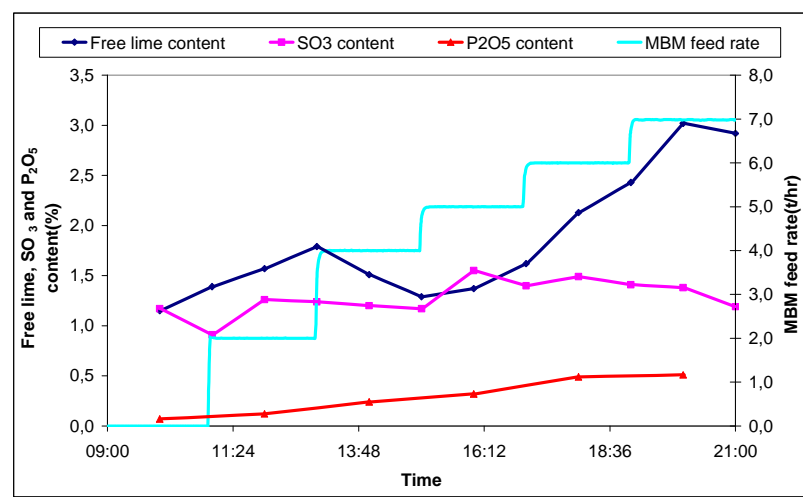

Fig. 4. Free lime, $\mathrm{SO}_{3}$ and $\mathrm{P}_{2} \mathrm{O}_{5}$ content of the clinker

The $\mathrm{SO}_{3}$ content is also in an acceptable range (less than $1.5 \%)$ for the standard clinker, and the level appears not to be impacted by the MBM feeding.

The main issue indicated here is the increase in free lime content with increments of MBM feeding. When the MBM feeding rate is $6 \mathrm{t} / \mathrm{hr}$, the free lime content is slightly lower than the maximum allowable limit, 2.5\%. It is even higher (3\%) when the MBM feeding rate is $7 \mathrm{t} / \mathrm{hr}$. The final slight decrement of free lime shown in the Figure 4 (although still above the recommended limit) is likely due to a reduction in the raw meal feeding rate by $10 \mathrm{t} / \mathrm{hr}$ (i.e. total raw meal feeding rate of $210 \mathrm{t} / \mathrm{hr}$ ) in the last hour of the test. Therefore, it can be concluded that even with low clinker production rate, $7 \mathrm{t} / \mathrm{hr}$ MBM feeding is not appreciable. The high free lime content reveals improper burning of the raw meal and poorer quality of the clinker.

One possible reason for the increase in free lime content with MBM feeding is the introduction of extra calcium at the kiln outlet via a high calcium phosphate content in MBM. The extra calcium, being fed from the outlet side of the kiln, might not have sufficient residence time in the rotary kiln and hence add to the clinker without proper combination with the other oxides.

Figure 5 indicates the maximum theoretical free lime content that could be added to the clinker via the MBM feed, conservatively assuming that all the calcium which enters with MBM, will end up as free lime. For these theoretical calculations, the ash content of MBM and the free lime percentage at the reference conditions (when feeding only coal) are 27.2\% (Table II) and 1.27\% (Figure 4), respectively. The $\mathrm{CaO}$ content of MBM ash is $48.9 \%$ (Table II).

The results shown in Figure 5 indicate that when the MBM feeding rate is high, the experimental free lime content is considerably higher than the maximum theoretical values which were estimated based on the stoichiometry of the clinker reactions. Consequently, additional feeding of calcium could explain only 54\% of the increase in free lime content due to MBM feeding at 7 $\mathrm{t} / \mathrm{hr}$. Therefore, there must be other phenomena as well, along with above mentioned reason, which cause the $138 \%$ increase in free lime content at $7 \mathrm{t} / \mathrm{hr}$ MBM feeding.

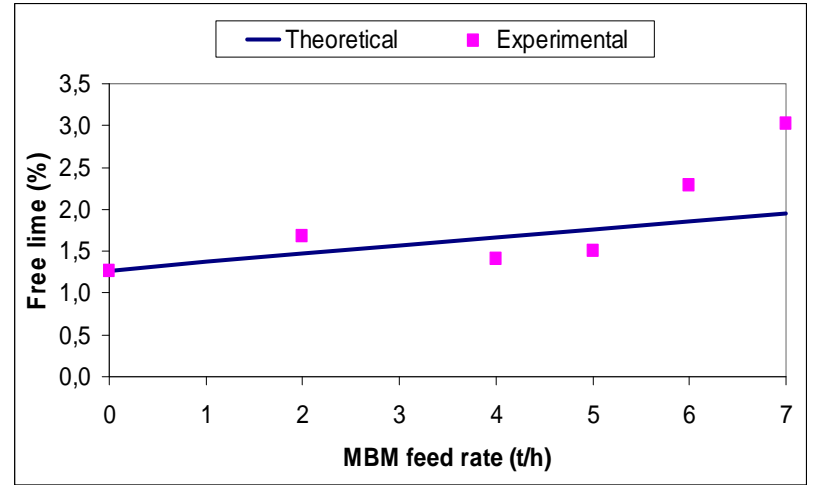

Fig. 5. Resulting free lime in clinker by feeding MBM (assuming all $\mathrm{CaO}$ from $\mathrm{MBM}$ ends up as free lime in clinker)

It has been shown [7], [23]-[27] that a high level of phosphorous stabilizes belite and hence inhibits the reaction between $\mathrm{CaO}$ and belite to form alite. Due to this reason the free lime content can be increased.

Still another potential reason for an increase in free lime content is reduced flame temperature: If the temperature is not sufficiently high, part of the $\mathrm{CaO}$ in the raw materials may not combine with other oxides, and the free lime level increases. Reduced flame temperatures could be due to lower heating value (Table II) or larger particle size (Figure 2), as larger particles mean increased burnout time, which will most likely reduce the maximum flame temperature and hence the local heat flux from the flame to the material bed in the kiln. For a given percentage, the particle size of MBM is more than 10 times bigger than that of coal. While the maximum size of the coal particles is around $200 \mu \mathrm{m}$, the MBM distributes up to $5000 \mu \mathrm{m}$. However, even if the burnout time of large particles is higher, this may be partly offset by a higher content of volatiles in MBM (Table II) via faster fuel ignition.

\section{Process data}

The typical $\mathrm{O}_{2}$ concentration maintained in the kiln inlet (where the precalcined meal is fed) is 3-4\% (dry basis). The sudden peaks observed in the graph of $\mathrm{O}_{2}$ at kiln inlet in Figure 6 are mainly due to automatic air cleaning of the sensor probe at given intervals.

Typically, the CO concentration should be $0 \%$ at the kiln inlet, but up to $0.1 \%$ is acceptable. It is observed that a high $\mathrm{O}_{2}$ concentration at the kiln inlet causes less $\mathrm{CO}$ production, which is generally an obvious fact. However, more importantly, the result shown in Figure 6 also reveals that the $\mathrm{CO}$ concentration in the kiln inlet was in an acceptable range throughout the experiment; it did not increase as a result of MBM feeding.

It is observed in Figure 7 that the $\mathrm{NO}_{\mathrm{x}}$ level at the kiln inlet was not affected by MBM feeding, indicating that the sum of thermal $\mathrm{NO}_{\mathrm{x}}$ formation and fuel $\mathrm{NO}_{\mathrm{x}}$ formation in the kiln was more or less constant.

The kiln drive current (Figure 7) is in a typical range for smooth operation, ie 400-500 A for OPC clinker production. A drop in the kiln drive current would be an indication of reduced melt formation in the kiln, which 
would give a poorer clinker quality. However, the kiln drive current appears not to be impacted by the feeding of MBM. This suggests that the thermal $\mathrm{NO}_{\mathrm{x}}$ formation in the kiln was not considerably changed, which indicates that also the fuel $\mathrm{NO}_{\mathrm{x}}$ formation stayed at the same level. This suggests that reduced flame temperture, as discussed in Subsection 3B, was actually not contributing significantly to the increase in free lime content.

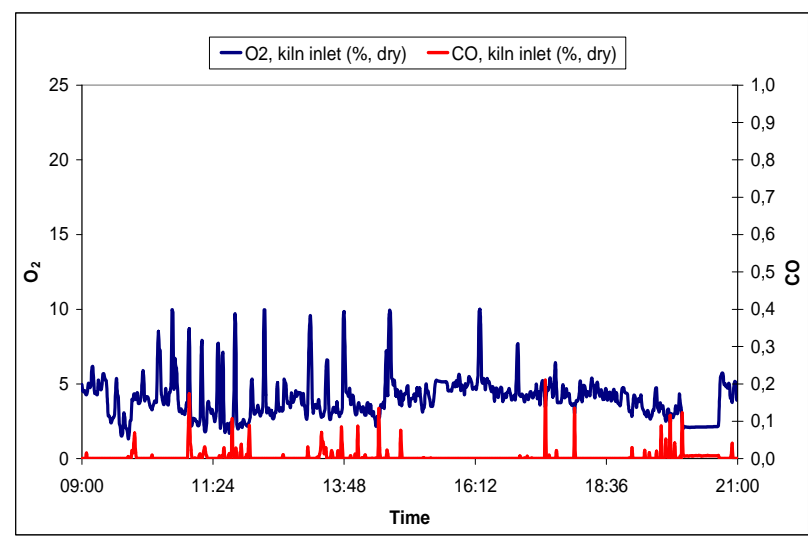

Fig. 6. $\mathrm{O}_{2}$ and $\mathrm{CO}$ concentrations at kiln inlet

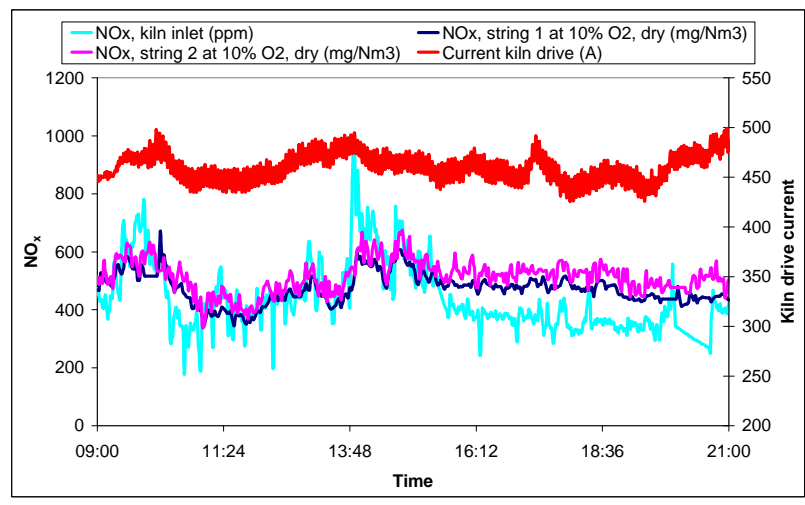

Fig. 7. $\mathrm{NO}_{\mathrm{x}}$ concentrations and kiln drive current

As also shown in Figure 7, the average $\mathrm{NO}_{\mathrm{x}}$ concentration in the stack (average of two strings) is around 500 $\mathrm{mg} / \mathrm{Nm}^{3}$ (dry, $10 \% \mathrm{O}_{2}$ ), and hence considerably lower than the emission limit of $800 \mathrm{mg} / \mathrm{Nm}^{3}$ (dry, 10\% $\mathrm{O}_{2}$ ). And the $\mathrm{NO}_{\mathrm{x}}$ emission seems to be unaffected by the MBM feeding. The CO concentration in the stack (not shown) was $0 \%$ during the entire test; any CO in the kiln inlet (Figure 6) will be completely oxidized in the precalciner part of the kiln system.

The above figures confirm that the emissions were considerably lower than the emission limits during the test, and not negatively affected by the feeding of MBM.

Figure 8 and 9 demonstrate the smooth operation of Pfister feeder system which was used for MBM feeding.

The pipeline pressure between the Pfister outlet and the kiln burner increased proportionally to the MBM feeding rate, indicating a smooth flow of the MBM. The speed of the weigh feeder motor was in a range of 0-3200 rpm. The motor operated around $15 \%$ of full capacity, even with maximum MBM feeding rate. The mass in the hopper was smoothly controlled between $300 \mathrm{~kg}$ and $1500 \mathrm{~kg}$. No matter the discharge rate, the material level inside the weigh feeder was always kept at $100 \%$ for simple and accurate operation.

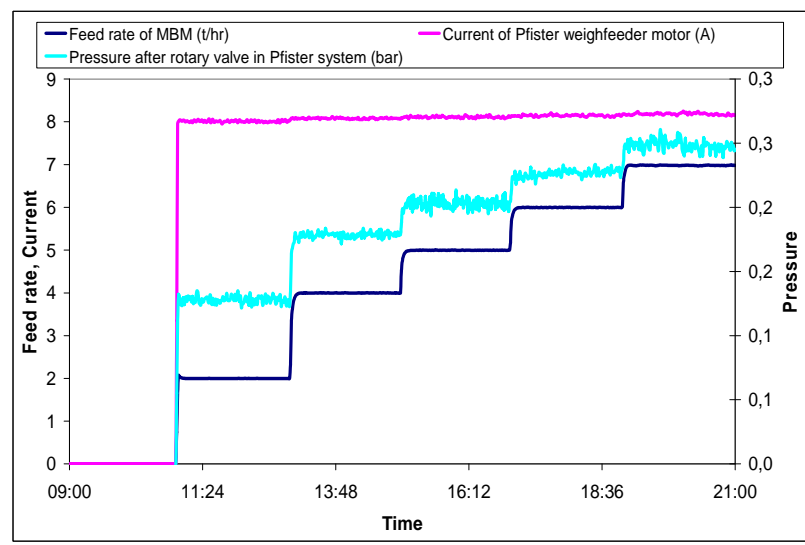

Fig. 8. The effects of feeding rate increment on current of Pfister weigh feeder and pressure after rotary valve

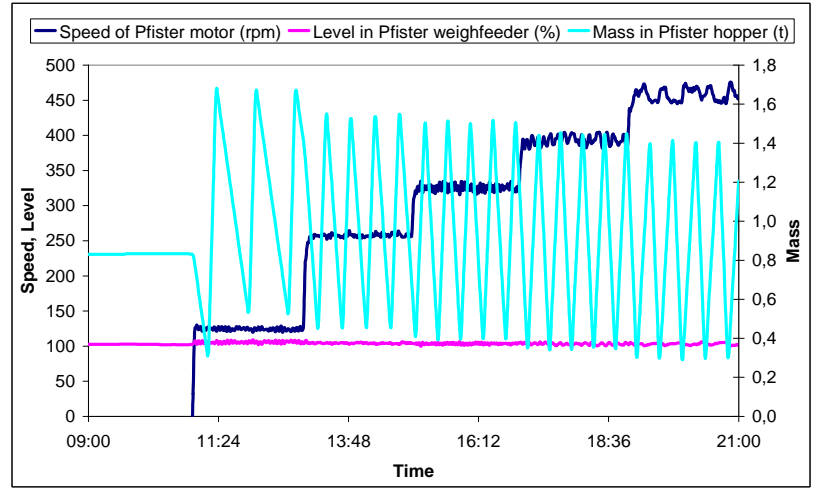

Fig. 9. Level variation of Pfister hopper, weigh feeder and speed of Pfister motor

Hence, it can be concluded that the Pfister feeder system operated smoothly during the whole test period, hence MBM is a material which is well suited for such a feeding system. Especially the material density (Table II) which should to be between 50 and $1500 \mathrm{~kg} / \mathrm{m}^{3}$, the particle size distribution and the moisture content of MBM were all very well fit with the feeding system requirements.

It should also be noted that, not only the feeding system, but also the entire kiln system, including precalciner, cyclones and bypass system, were operated smoothly throughout the test period, even though all operational data are not presented here.

\section{D. $\mathrm{CO}_{2}$ savings}

The above mentioned results showed that $6 \mathrm{t} / \mathrm{hr}$ of MBM feeding appears to be acceptable with respect to product quality, emissions and operation of the whole kiln system. From Table I it is seen that $6 \mathrm{t} / \mathrm{hr}$ feeding of MBM exactly halves the coal feeding rate compared to the reference conditions (i.e. when only coal is fed), resulting in 50\% reduction in net $\mathrm{CO}_{2}$ emissions from the kiln burner combustion. However, to be on the safe side, and also taking into account inherent delay effects in the kiln system, one should probably set the maximum limit somewhat lower; for example at $40 \%$ replacement. This is equivalent to an annual net $\mathrm{CO}_{2}$ emission reduction of 
about 90,000 tons for the given plant, which corresponds to $10 \%$ of the total annual $\mathrm{CO}_{2}$ emissions of the plant.

\section{Conclusion}

The test results reveal the possibility of significant replacement of coal by MBM in the rotary kiln main burner without negatively affecting product quality, production rate, emissions or overall operation. No significant impacts on emissions or operation of the kiln system were observed, regardless of MBM feeding rate. The $\mathrm{P}_{2} \mathrm{O}_{5}$ content of the clinker increased with $\mathrm{MBM}$ feeding, but was still within the internal quality limit. The most important impact of the MBM feeding was on the free lime content of the clinker: When replacing more than $50 \%$ of the coal (6 t/hr of MBM feeding) the free lime level increased to more than $3 \%$, which is not acceptable from a product quality point of view. To be on the safe side, considering long-term operation, the replacement ratio should not exceed $40 \%$. Promisingly, if $40 \%$ of the kiln burner coal is substituted by MBM, around $10 \%$ of the total annual $\mathrm{CO}_{2}$ emissions from the plant can be avoided.

\section{Acknowledgement}

The authors would like to thank MSc students Øyvind Hasli, Liu Li and Rafid Al-Hawani for doing part of the laboratory work.

\section{References}

[1] D. N. Huntzinger and T. D. Eatmon, “A life-cycle assessment of Portland cement manufacturing: comparing the traditional process with alternative technologies”, Journal of Cleaner Production 2009, pp. 1-8.

[2] L. A. Tokheim, "The impact of staged combustion on the operation of a precalciner cement kiln”, Ph.D. thesis 1999, Telemark University College/ Norwegian University of Technology and Science.

[3] Directive 2003/87/EC of the European Parliament and of the Council of 13 October 2003 establishing a scheme for greenhouse gas emission allowance trading within the Community and amending Council Directive 96/61/EC 2003, European Commission.

[4] L. A. Tokheim, "Burning chamber installation for increased use of alternative fuels at Norcem Brevik", Proc. 7th International KHD Humboldt Wedag Symposium 2006, Cologne, Germany, 17-19 May.

[5] L. A. Tokheim, "Kiln system modification for increased utilization of alternative fuels at Norcem Brevik", Cement International 4 2006, 4, pp. 3-8.

[6] W. K. H. Ariyaratne, L. A. Tokheim and M. C. Melaaen "Net $\mathrm{CO} 2$ emissions from solid recovered fuels: Evaluation of the selective dissolution method”, Proc. ASME-ATI-UIT 2010 Conference on Thermal and Environmental Issues in Energy Systems 2010, Sorrento, Italy, 16-19 May.

[7] D.C. Nastac, U. Kaantee, J. Liimatainen, M. Hupa and M. Muntean, "Influence of $\mathrm{P}(\mathrm{V})$ on the characteristics of calcium silicates and the hydration of clinkers", Advances in Cement Research 2007, 19, No.3, pp. 93-100.

[8] U. Kaantee, R. Zevenhoven, R. Backman and M. Hupa, "Cement manufacturing using alternative fuels and the advantages of process modelling”, Fuel Processing Technology 2004, 85, pp. 293- 301.
[9] J. A. Conesa, A. Fullana and R. Font, "Thermal decomposition of meat and bone meal”, J. Anal. Appl. Pyrolysis 2003, 70, pp. 619-630.

[10] G. Skodras, P. Grammelis and P. Basinas, "Pyrolysis and combustion behaviour of coal-MBM blends", Bioresource Technology 2007, 98, pp. 1-8.

[11] L. Fryda, K. Panopoulos, P. Vourliotis, E. Kakaras and E. Pavlidou, "Meat and bone meal as secondary fuel in fluidized bed combustion”, Proceedings of the Combustion Institute, Fuel 2007, 31, pp. 2829-2837.

[12] I. Gulyurtlu, D. Boavida, P. Abelha, M. H. Lopes and I. Cabrita, "Co-combustion of coal and meat and bone meal", Fuel 2005, 84, pp. 2137-2148.

[13] L. Fryda, K. Panopoulos, P. Vourliotis, E. Pavlidou and E. Karakas, "Experimental investigation of fluidised bed cocombustion of meat and bone meal with coals and olive bagasse”, Fuel 2006, 85, pp. 1685-1699.

[14] E. Deydier, R. Guilet, S. Sarda and P. Sharrock, "Physical and chemical characterisation of crude meat and bone meal combustion residue: 'waste or raw material?'”, Journal of Hazardous Materials 2005, 121, pp. 141-148.

[15] A. Chaala and C. Roy, "Recycling of meat and bone meal animal feed by vacuum pyrolysis”, Environ. Sci. Technol. 2003, 37, pp. 4517-4522.

[16] M. Ayllon, G. Gea, M. B. Murillo, J. L. Sanchez and J. Arauzo, "Kinetic study of meat and bone meal pyrolysis: an evaluation and comparison of different possible kinetic models”, J. Anal. Appl. Pyrolysis 2005, 74, pp. 445-453.

[17] G. Skodras, P. Grammelis, P. Basinas, S. Kaldis, E. Kakaras and G. P. Sakellaropoulos, "A kinetic study on the devolatilisation of animal derived byproducts", Fuel Processing Technology 2007, 88, pp. 787-794.

[18] E. J. Cummins, K. P. McDonnell and S. M. Ward, "Dispersion modelling and measurement of emissions from the co combustion of meat and bone meal with peat in a fluidised bed”, Bioresource Technology 2006, 97, pp. 903-913.

[19] K. McDonnel, J. Desmond, J. J. Leahy, R. Howard-Hildige and S. Ward, "Behaviour of meat and bone meal/peat pellets in a bench scale fluidised bed combustor”, Energy 2001, 26, pp. 81-90.

[20] N. O. Knudsen, N. Henriksen, I. Hundebøl and K. WieckHansen, "Co-combustion of meat and bone meal with natural gas”, VGB PowerTech 2003, 83, pp. 81-83.

[21] J. Beck, J. Brandenstein, S. Unterberger and K. R. G. Hein, "Effects of sewage sludge and meat and bone meal cocombustion on SCR catalysts”, Appl. Catal. B: Environ. 2004, 49, pp. 15-25.

[22] Pfister, Rotor weighfeeder TRW-S/D, Highly accurate and reliable gravimetric feeding for a variety of solid secondary fuels, Product brochure 2009, Germany.

[23] R. W. Nurse, "The effect of phosphate on the constitution and hardening of Portland cement”, Journal of applied chemistry 1952, 2, No. 12, pp. 708-716.

[24] W. Gutt, "Manufacture of Portland cement from phosphate raw materials", Proceedings of the fifth ICCC 1968, vol. I, pp. 93-105.

[25] L. Halicz and Y. Nathan, "The influence of $\mathrm{P}_{2} \mathrm{O}_{5}$ on clinker reactions”. Cement and Concrete Research 1984, 14, No.1, pp. 11-18.

[26] B. Matkovic, V. Carin and J. F. Young, "Dicalcium silicates doped with phosphates", Proceedings of the $8^{\text {th }}$ ICCC 1986, Vol. II, pp. 276-281.

[27] A. Diouri, A. Boukhari, J. Aride, F. Puertas and T. Vazquez, "Research of the lime rich portions of the $\mathrm{CaO}$ $\mathrm{SiO}_{2}-\mathrm{P}_{2} \mathrm{O}_{5}$ system", Materiales de construccion 1995, 45, 237, pp. 3-13. 